\title{
Validation of a questionnaire on the use of Interactive Response System in Higher Education
}

\author{
Ángel Custodio Mingorance-Estrada ${ }^{1}$ \\ (1D) https://orcid.org/0000-0003-4478-3011 \\ Juan Granda-Vera² \\ (1D) https://orcid.org/0000-0001-6888-7785 \\ Gloria Rojas-Ruiz ${ }^{1}$ \\ (1D) https://orcid.org/0000-0001-8541-383X \\ Inmaculada Alemany-Arrebola ${ }^{3}$ \\ (D) https://orcid.org/0000-0002-4127-3502
}

${ }^{1}$ University of Granada, Department of Didactics and School Organization, Melilla, ES, Spain.

${ }^{2}$ University of Granada, Department of Didactics of Corporal Expression, Melilla, ES, Spain.

${ }^{3}$ University of Granada, Department of Developmental and Educational Psychology, Melilla, ES, Spain.
Objective: this study aims to design and validate a questionnaire to measure the students' perception of the use of IRS as a technopedagogical resource in the classroom. Method: a 24 items questionnaire (Interactive Response System for the Improvement of the Teaching-Learning Process) was designed ad hoc for this research and applied to 142 university students. Results: both the exploratory and confirmatory factorial analysis yielded 3 dimensions: classroom environment, teaching-learning processes and learning assessment. The results obtained both in reliability (Cronbach's alpha $=0.955$ ) and in the Confirmatory Factor Analysis $(X 2 / d f=1.944$, $\mathrm{CFI}=0.97 ; \mathrm{GFI}=0.78 ; \mathrm{RMR}=0.077 ; \mathrm{RMSEA}=0.08$ ) reveal highly satisfactory indices. Conclusion: statistical analyses confirm that this instrument is a valid, reliable, and easy-to-apply tool for professors to evaluate the student perception of studentcentred learning.

Descriptors: Education; Higher Education; Learning; Validation Study; Surveys and Questionnaires; Technology Education.

\section{How to cite this article}

Mingorance-Estrada AC, Granda-Vera J, Rojas-Ruiz G, Alemany-Arrebola I. Validation of a questionnaire on the use of Interactive Response System in Higher Education. Rev. Latino-Am. Enfermagem. 2021;29:e3418. [Access $\underset{\text { month }}{\mathrm{f}} \underset{\mathrm{fay}}{\frac{1}{\mathrm{f}}} \frac{1}{\text { year }}$; Available in: DOI: http://dx.doi.org/10.1590/1518-8345.3374.3418. 


\section{Introduction}

Higher Education must establish a space for the exchange of practical experiences that promotes knowledge and research within the common framework of the European and Ibero-American Higher Education Area(1-2).

The implementation of student-centered learning is oriented to establish a model that effectively integrates technology with knowledge of didactic mediation, evolving towards the Technological Pedagogical and Content Knowledge Model (TPACK). This system combines disciplinary, pedagogical and technological knowledge, but always considering the context in which it intervenes ${ }^{(3-4)}$, and increasing the interaction between professors and students within a critical dialogical approach(2).

Some authors consider necessary to establish didactic knowledge through the relationship between different types of knowledge (coming from the own discipline, general pedagogy and students) and the professor's biography(5). Thus, during the nursing initial training, both the pedagogical aspects, including the implementation of Interactive Response System (hereinafter IRS) with remote answering devices to monitor students' progress, and the involvement of expert professors lead to highquality teaching, among other issues ${ }^{(6)}$.

In this regard, encouraging professors to integrate technology into the classroom is crucial, as highlighted in the Horizon Report ${ }^{(7)}$, since it will significantly impact on education in the coming years. To do this, university professors must use the technological tools they are familiar with, as well as access new technological resources to improve teaching processes ${ }^{(8)}$.

Similarly, technological changes in university professors follow a tendency and are not radical; they introduce those that are consistent with their teaching practices into the learning activities they normally carry out ${ }^{(9)}$.

In order to face these technological challenges, an inversion of learning process is required; students should be provided with materials in various formats, so that they can carry out preliminary work before arriving at the classroom, incorporating IRS to verify the improvements in the student centered-learning process ${ }^{(10-12)}$. IRS has been already integrates in some university classes (13). Thus, the available literature about Higher Education on the use of this technology in recent years focuses on the fields of Science, Technology, Engineering and Mathematics, Sociology, Humanities, Health (Medicine and Nursing), Business Administration and English language ${ }^{(13-14)}$.

The reviewed studies indicate that integrating IRS in university classrooms improves three main areas: the classroom environment, the teaching-learning processes and learning assessment ${ }^{(15-20)}$. Thus, defining the possibilities and limitations of this tool is increasingly important for the improvement of the quality of Higher Education $^{(6)}$.

Concerning the classroom environment factor, IRS increases attendance ${ }^{(21)}$ and student participation ${ }^{(22-25)}$, resulting in a higher level of involvement during classes in comparison to the traditional methodology(23,26-27). Within the learning factor, some studies establish that frequent and positive interaction makes classes more dynamic when using IRS ${ }^{(13,28-29)}$, promoting active learning(30-32). In addition, attention ${ }^{(33-34)}$, concentration ${ }^{(35)}$ and memory ${ }^{(36-37)}$ are encouraged during the learning process. Extensive research suggests that a better performance is the result of the use of IRS, as some studies indicate(31-32,38-41), although other studies do not find such an effect(42). In relation to the assessment factor, the findings of the literature support the capacity of IRS as a tool for assessment and feedback ${ }^{(43-44)}$. It is considered that both students and professors benefit from the feedback they receive with the use of this educational technology ${ }^{(20,27)}$. All of this leads to a key learning process for the interaction of knowledge and know-how ${ }^{(45)}$.

The aim of this study is to design and validate this study aims to design and validate a questionnaire to measure the students' perception of the use of IRS as a technopedagogical resource in the classroom.

\section{Method}

The design was transectional and descriptive, as the data were collected in a single time in order to describe the phenomenon and analyze it at a certain time.

The research was carried out at Melilla Campus of the University of Granada (Spain), located in North Africa, whose students attend to the Health Sciences, Social and Legal Sciences, and Education and Sports Sciences schools. For this purpose, an intentional non-probabilistic sample was carried out. The selection criteria have been: firstly, professors who use technology in their classrooms, specifically interactive response devices. And secondly, the willingness of the students to participate in this study. Therefore, the sample comprises 142 students: 110 women $(77.5 \%)$ and 32 men (22.5\%). In relation to the academic year, 17 students are in first year (12\%), 95 in second year (66.9\%) and 30 in third year (21.1\%).

To carry out this study, an ad hoc questionnaire was designed for this research, "Interactive Response System for the Improvement of the Teaching-Learning Process (IRS-ITLP)".

In relation to the items of the IRS-ITLP, they were written after an extensive bibliographic review on the three factors highlighted above ${ }^{(21,46-47)}$. Despite of the absence of experts on this field, this process provides validity to the questionnaire items. 
We started with 65 items grouped into categories ${ }^{(48)}$. After the analysis of the items, we selected 35 items that were grouped into the three dimensions: learning environment, process and assessment. Regarding the questionnaire response format, a Likert type scale was used, with 5 response alternatives, ranging from 1 , totally disagree, to 5, totally agree.

The research was oriented to different degrees of the University of Granada (Spain), all of them being subjects concerning the basic formation of the students. For this purpose, the collaboration of the teaching staff was requested to participate as volunteer in this project and to integrate IRS in their classes.

The use of the IRS in these basic training subjects was carried out throughout the semester of the 2016-17 academic year, before, during and at the end of the classes. At the end of the semester, the IRS-ITLP questionnaire was applied the last week of the semester, with a duration of approximately 15 minutes, to find out the perception of the experience. Students were asked to agree to participate in this experience voluntarily and anonymously, following the rules of the Committee on Publication Ethics (COPE).
The statistical software SPSS version 20.0 has been used for the statistical processing of the data. To know the reliability of each group of items, Cronbach's alpha was used, and for the validity of the questionnaire, an Exploratory Factor Analysis was carried. For the Confirmatory Factor Analysis, the program LISREL 8.8 was used.

\section{Results}

Firstly, the reliability of the IRS-ITLP questionnaire consisting of 35 elements was analyzed using Cronbach's alpha internal consistency coefficient, which was 0.965 . Although this index was high, we proceeded to eliminate those items whose item-total correlation was inferior to 0.20 . Finally, the questionnaire was made up of 24 items with a $a=0.955$, showing homogeneity indexes ranging from 0.42 to 0.85 .

Subsequently, the means, standard deviations, asymmetry, and item-total correlations of each of the items were obtained. As can be seen in Table 1 , the asymmetry is negative in all items, which shows a greater concentration of responses corresponding to the high scores in those items.

Table 1 - Descriptive values of the items in the IRS-ITLP questionnaire. Granada, Spain, 2017

\begin{tabular}{|c|c|c|c|c|c|}
\hline $\mathbf{N}^{\circ}$ & Items & $\mathbf{M}^{*}$ & $\mathbf{S D}^{\dagger}$ & Asymmetry & Correl. item-total \\
\hline 1 & I am more focused during the classes since the implementation of IRS & 3.40 & 1.15 & -0.477 & 0.689 \\
\hline 2 & $\begin{array}{l}\text { Thanks to IRS, I measure if I am following correctly the contents of the subject during } \\
\text { the classes }\end{array}$ & 3.81 & 1.01 & -0.658 & 0.619 \\
\hline 5 & During my experience with the IRS I have a good time learning & 3.52 & 1.18 & -0.559 & 0.566 \\
\hline 9 & IRS is used to find out the initial knowledge of the students & 3.54 & 1.258 & -0.595 & 0.488 \\
\hline 10 & The use of IRS is carried out by experienced professors to provide good feedback & 3.97 & 0.891 & -0.616 & 0.610 \\
\hline 14 & $\begin{array}{l}\text { The use of IRS helps me to develop my comprehension on the contents I am } \\
\text { working on }\end{array}$ & 3.59 & 1.162 & -0.666 & 0.639 \\
\hline 15 & The use of the IRSs makes the classes enjoyable and dynamic & 3.82 & 1.119 & -0.877 & 0.656 \\
\hline 18 & The use of IRS improves my learning performance & 3.76 & 1.129 & -0.653 & 0.762 \\
\hline 19 & The continuous use of the IRS increases my class attendance & 3.70 & 1.266 & -0.793 & 0.579 \\
\hline 20 & $\begin{array}{l}\text { The use of IRS allows you to know and compare your colleagues' answers with your } \\
\text { own answers }\end{array}$ & 3.42 & 1.234 & -0.646 & 0.441 \\
\hline 21 & $\begin{array}{l}\text { The use of the IRS allows to correct mistakes or misunderstandings about the } \\
\text { subject contents during the classes }\end{array}$ & 3.71 & 1.121 & -1.032 & 0.558 \\
\hline 22 & I am more interested in classes when using IRS & 3.65 & 1.066 & -0.698 & 0.768 \\
\hline 24 & I like the use of IRS as an attendance control & 3.65 & 1.005 & -0.605 & 0.699 \\
\hline 29 & The use of IRS improves motivation during classes & 3.83 & 1.111 & -0.825 & 0.753 \\
\hline 30 & The use of IRS allows active discussion of misconceptions to build knowledge & 3.80 & 1.168 & -0.771 & 0.792 \\
\hline 35 & $\begin{array}{l}\text { The use of the IRS evaluates my comprehensive knowledge of the contents in each } \\
\text { of the topics covered during the classes }\end{array}$ & 3.99 & 0.971 & -1.211 & 0.788 \\
\hline 36 & $\begin{array}{l}\text { The use of IRS promotes regular study of the subject to be better prepared for } \\
\text { classes }\end{array}$ & 3.64 & 1.094 & -0.762 & 0.715 \\
\hline 42 & $\begin{array}{l}\text { The use of IRS allows you to be more confident when asking questions during } \\
\text { classes }\end{array}$ & 3.76 & 1.254 & -0.739 & 0.787 \\
\hline 46 & $\begin{array}{l}\text { The use of the IRS is done at the end of the classes to review the contents explained } \\
\text { during the session }\end{array}$ & 3.80 & 1.100 & -0.736 & 0.772 \\
\hline 47 & $\begin{array}{l}\text { The use of IRS makes the classes more pleasant and interactive compared to } \\
\text { traditional classes }\end{array}$ & 3.86 & 1.082 & -0.804 & 0.769 \\
\hline 48 & The use of IRS improves your participation in classes behind anonymity & 3.87 & 1.104 & -0.773 & 0.712 \\
\hline 53 & $\begin{array}{l}\text { The answers provided through the IRS increase my confidence in the classes after } \\
\text { verifying that I answered correctly }\end{array}$ & 3.44 & 1.164 & -0.420 & 0.700 \\
\hline 59 & IRS provides valuable information to improve your learning process & 4.09 & 1.017 & -1.007 & 0.687 \\
\hline 65 & The use of IRS improves the understanding of the contents explained in class & 3.87 & 1.160 & -0.911 & 0.727 \\
\hline
\end{tabular}

${ }^{*} \mathrm{M}=\mathrm{Mean} ;{ }^{+} \mathrm{SD}=$ Standard deviation 
Since any study about the factor analysis of the IRSITLP questionnaire had previously been published, before performing a Confirmatory Factor Analysis it was convenient to carry out an Exploratory Factor Analysis (EFA) to explore how the items are grouped into factors. To ensure that the data fit a factor analysis model, the data were subjected to the Kaiser-Meyer-Olkin test $(\mathrm{KMO}=0.941)$ and to the Bartlett's Test for Sphericity $\left(c^{2}=2446.206\right.$; df $=300$; $p<0.001)$. The values indicate that a factor analysis is a suitable technique to structure the information contained in the matrix. The EFA reveals the existence of 3 factors that explain $61.61 \%$ of the total variance, being this proportion acceptable. In addition, the item communalities are above $h^{2}=0.40$, ranging from 0.421 "The continuous use of IRS increases my class attendance" to 0.791 "The use of IRS allows you to know and compare your colleagues' answers with your own answers".

Table 2 shows the factors, items, factor loadings and reliability of each dimension, as well as the interpretation of these factors. To determine the dimensions, the factorial loadings criterion has been followed, being the cutoff value $0.30^{(49)}$.

Table 2 - Factors, items and loadings obtained in the Exploratory Factor Analysis of the IRS-ITLP. Granada, Spain, 2017

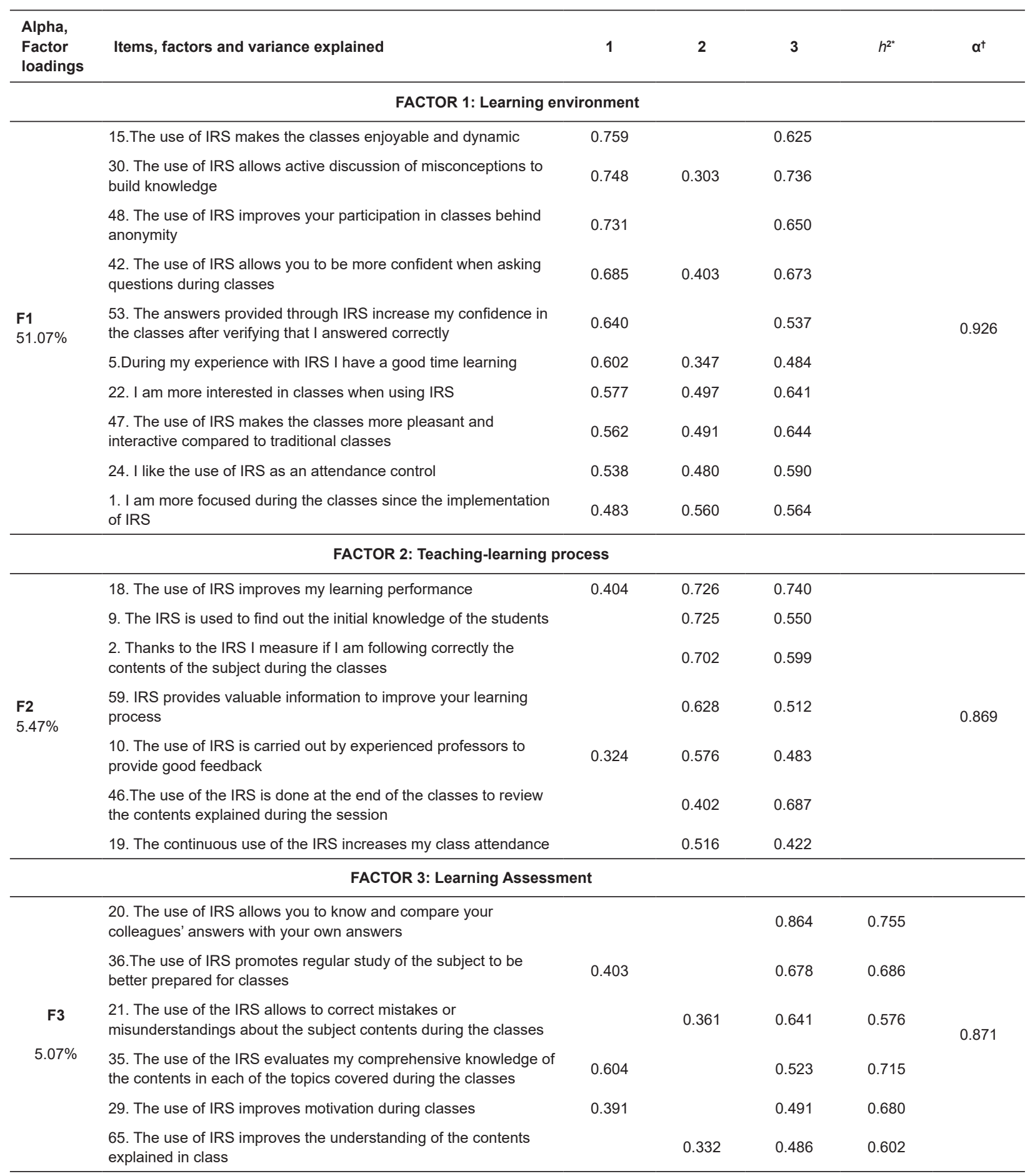

${ }^{*} h^{2}=$ Communality $;{ }^{+} a=$ Cronbach's alpha 
Subsequently, the Confirmatory Factor Analysis was performed, and the 3-factors model was tested. The maximum likelihood estimation method was used to analyze the correlation matrix. The Goodness-of-Fit of the proposed model was evaluated using various indicators. The $x^{2} / d f(484.13 / 249)$ scores 1,944 , a value that is within the acceptable standards. Moreover, the Root Mean Square Residual (RMR) is 0.077 and the Root Mean Square
Error of Approximation (RMSEA) is 0.080 , being both indexes considered acceptable since they are between 0.5 and $.08^{(49)}$. The Goodness-of-Fit Index (GFI) and the Comparative Fit Index (CFI) (with values of 0.78 and 0.97 respectively) are within the tolerance limits. These results confirm that the 3 -factor model fits the data, so the model can be maintained as a plausible explanation for the proposed dimensional structure.

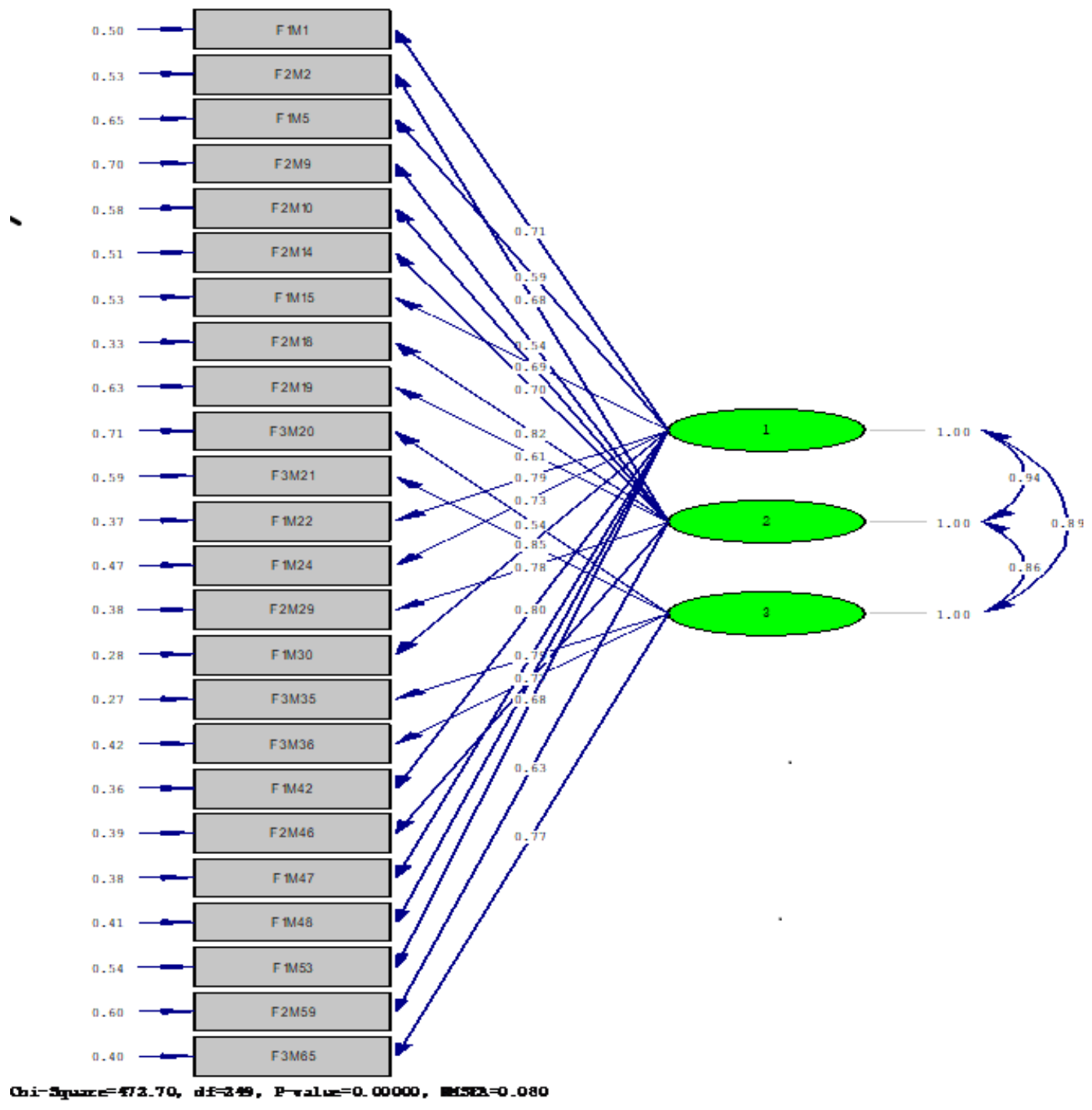

Figure 1 - Confirmatory factor analysis of the questionnaire "Interactive Response System for the Improvement of the Teaching-Learning Process"

To test the reliability of the instrument, a Cronbach's alpha test is carried out, obtaining a total value with a $a=$ 0.955 and the dimensions that make it up, obtaining values that range from $a=0.922$ for factor 1 , "Environment", to $a=0.869$ in factor 2 "Teaching-learning process". These data show that the reliability of the questionnaire is good in all the factors, being lower in factor 3, "Assessment". Although this statistic has been widely used in social research, it should be complemented with other analysis, such as the Composite Reliability Index (CF) and the Mean Extracted Variance (MEV). The results obtained are shown in Table 3, being in all cases acceptable. 
Table 3 - Composite Reliability and Mean Extracted Variance from the factors in the IRS-ITLP questionnaire. Granada, Spain, 2017

\begin{tabular}{lcc}
\hline Factors & CF $^{\star}$ & MEV $^{\dagger}$ \\
\hline F1: Learning Environment & 0.955 & 0.544 \\
F2: Teaching-learning process & 0.930 & 0.508 \\
F3: Learning assessment & 0.863 & 0.540 \\
\hline
\end{tabular}

${ }^{*} \mathrm{CF}=$ Composite Reliability $;{ }^{+} \mathrm{MEV}=$ Mean Extracted Variance

\section{Discussion}

The aim of this study is the construction of a valid and reliable questionnaire to measure the use of IRS in university student-centred learning. The results provide empirical evidence of the validity of this intervention model using IRS, which allows university professors in general, and health sciences professors in particular, to transform the teaching-learning process. This model encourages and involves students in this process through a more active approach for $21^{\text {st }}$ century professors, who can measure students' perception on the use of IRSs, an advance that really makes a difference.

Moreover, apart from a technopedagogical resource, it turns into a playful activity for students in a nongame context, being this model included in an emerging educational methodology called Gamification. In summary, this model provides the opportunity to drastically transform traditional classrooms so that it improves the classroom environment, the learning process and their academic performance in a playful and enjoyable way.

The IRS-ITLP questionnaire consists of 24 items that are grouped into 3 factors: Learning Environment, Teaching-Learning Process and Assessment. In relation to the quality of the items, which was measured through item-to-total correlation, the data indicates high rates ranging from 0.488 to 0.787 . These values show a high internal consistency supporting the ideas that the items are correlated, and the scale is accurate. Furthermore, a descriptive analysis on the items show that there is negative asymmetry, which reveals that university students tend to agree with the questionnaire statements.

As for the reliability of the scale, the value for Cronbach 's alpha is 0.965 , indicating a high reliability. These data are in line with the composite reliability indexes of the 3 factors comprising IRS-ITLP, which reach optimum levels: $0.955,0.930$ and 0.863 for Environment, Teaching-Learning Process and Assessment, respectively, being the minimum acceptable value 0.70 .

Furthermore, the validity of the construct was tested through an Exploratory Factorial Analysis (EFA) and a Confirmatory Factorial Analysis (CFA). Firstly, the EFA was carried out since there were no similar validated instruments that measure the perception of university students towards learning; we only knew the dimensions that make up the construct according to the literature consulted.

To do so, firstly the data were assessed obtaining significant values both in the Kaiser-Meyer-Olkin test, $(\mathrm{KMO}=0.941)$ and the Bartlett's sphericity test $\left(c^{2}=\right.$ 2446.206; $\mathrm{df}=300 ; p<0.001)$. These values indicate that a factorial analysis was an adequate technique for interpreting the information contained in this matrix. This analysis yielded three clearly defined factors that explain $61.61 \%$ of the total variance. The results of the CFA confirm the three-factor model. The indexes of goodness used were $X^{2} / d f=1.944$ (which is within the established standards), the RMR is 0.077 and the RMSEA is 0.080 , which are considered acceptable as they are between 0.5 and $0.08^{(49)}$. In addition, the GFI representing the joint adjustment is 0.78 and CFI is 0.97 , so both values are within the tolerance limits. These results confirm that the data fit to the 3-factor model, supporting the proposed dimensional structure.

For all these reasons, these results allow us to be confident in the reliability and validity of this instrument. Therefore, the construction and validation of this questionnaire make possible the application of this instrument to measure the student's perception in the use of IRS in the learning process.

Regarding the factor "Learning environment", reliability was measured using the Cronbach's alpha coefficient, which scores 0.926 and suggests a high internal consistency. The EFA explains $51.7 \%$ of the total variance, being the factor with the highest punctuation in this questionnaire. Among the items comprising this dimension are: item 15: the use of IRS makes the classes enjoyable and dynamic, item 48: the use of IRS improves my participation in the classes behind anonymity, item 47: the use of IRS makes the classes more enjoyable and interactive compared to traditional classes, among others. This factor is decisive since university students with an adequate class environment increase class attendance(22) and improves their participation ${ }^{(13,17,44)}$. It also comes on interaction between professors and students ${ }^{(13)}$, and has a positive influence on attention (33-34) and concentration(35), as the studies analyzed show.

The second dimension, which corresponds to the "teaching-learning process" factor, shows an internal consistency index of 0.869 and explains $5.4 \%$ of the total variance, significantly lowering the weight of the factor. This dimension refers to those elements that are basic to acquire knowledge, such as debates and interaction between professors and students, which positively affects their learning process since it helps students to review and understand the contents. Among the items that make up this factor are: item 47 the use of IRS makes 
the classes more pleasant and interactive in comparison with traditional classes, item 59 IRS provides valuable information to improve my learning process, item 46 the use of IRS is done at the end of the classes to review the contents explained during the session.

These elements coincide with studies supporting that this working methodology improves performance ${ }^{(31-32,38-41)}$ thanks to the paradigm shift that implies active learning through the connection between knowledge and knowhow ${ }^{(45)}$ and the frequent and positive interaction, which resulted into more dynamic classes when IRS is used ${ }^{(13,28)}$. This method promotes material comprehension by acquiring a deeper knowledge, helping to review and understand the contents and improving long-term retention(36-37); the final result is an improvement in the learning process.

In relation to the third dimension, "Learning Assessment" presents a Cronbach's alpha of 0.871 , and the EFA explains $5.07 \%$ of the total variance, showing a similar percentage to the previous factor. This dimension is related to feedback and formative evaluation, which help to correct errors or misunderstandings about the contents of the subject worked on ${ }^{(4,20,40)}$. The items included in this factor are: item 20 the use of IRS allows you to know and compare your colleagues' answers with your own answers; item 36 the use of IRS promotes regular study of the subject to be better prepared for classes; item 35, The use of IRS evaluates my comprehensive knowledge of the contents in each of the topics covered during the classes. The immediate feedback has a positive impact on both the students in their learning process and the professor in their teaching process, driving the students' formative evaluation.

In this way, in our global context with no academic frontiers, the European and Latin American Higher Education areas meet the premise that university system must be in a continuous transformation towards active student learning and lifelong learning. In addition, it is necessary to establish evaluation and accreditation of the work carried out in universities, promoting the transference of knowledge between successive researches among different fields of knowledge. This is the way an interdisciplinary understanding can be developed to assess the reality and to question the traditional consideration of the fields of knowledge as isolated compartments separated by disciplinary boundaries.

Among the limitations of this research, we list the following: firstly, it is necessary to continue increasing the number of participants, since the sample is not excessively large, but it does provide a starting point for transferring it to other fields of knowledge. The reason for this is the limited number of professors at the Melilla Campus of the University of Granada who use technopedagogical resources such as IRS in their classrooms and integrate them to processes of active gamification methodology, which is why it is necessary to promote and explore these resources. It is therefore essential to raise awareness and train university professors in the TPACK (Technological Pedagogical and Content Knowledge) model as a conceptual framework that can guide professors when integrating technology into students' learning processes, which will promote emerging methodologies such as gamification.

Secondly, improving the instrument is crucial so that it can be used by professors in any field of knowledge and in any situation (as has been done during the COVID-19 confinement). The objective is launching an instrument for future periods, according to the Government and university approaches, that can be used in face-to-face training, B-Learning or E-Learning. Therefore, the instrument needs to be developed by including new items that assess this new virtual education models. In addition, we must deepen the influence of this instrument depending on the different disciplines of the Health Sciences, a research that we intend to carry out in the future. The application of technological advances in the university field comes on the active learning process of students, and it is necessary to know their opinion to achieve progress and improvement in teaching. Thirdly, it is necessary further quasi-experimental research in the several fields of university teaching to analyze the influence of gamified active methodology through these technopedagogical resources and traditional methodology, bearing in mind its scope or relationship with academic performance.

\section{Conclusion}

The contribution of this study to knowledge is the design, development and dissemination of a new instrument that allows the measurement and assessment of students' perception on the use of IRS during university training by using a technopedagogical resource in any field of knowledge (whether Health Sciences, Social and Legal Sciences, Arts and Humanities, or Engineering and Architecture). The instrument considers three fundamental factors: learning environment, teaching-learning process and assessment. This questionnaire can be applied in the classroom during the training, helping to improve the teaching-learning processes. In this sense, Health Sciences professors must establish and explore innovative ways to involve students and stimulate active learning. It is important to incorporate active methods by using interactive response commands in disciplines such as nursing, medicine, pharmacy, paramedical education, psychology, dentistry, physiotherapy, speech therapy, biotechnology, epidemiology, genetics, biochemistry, occupational therapy, human nutrition and dietetics, 
among others. This instrument provides a positive pedagogical approach in the teaching-learning process for Health Sciences professors and students, improving the academic performance with the purpose of acquiring a deep knowledge of the subjects.

\section{References}

1. Sotillo JA, Rodrígue I, Echart E, Ojeda T. El Espacio Iberoamericano de Educación Superior. Diagnóstico y propuestas institucionales. Madrid: Fundación Carolina, CeALCI; 2009.

2. Mingorance AC, Granda J, Rojas G, Alemany I. Flipped Classroom to Improve University Student Centered Learning and Academic Performance. Soc Sci. 2019;8(11):315-28. doi: https://doi.org/10.3390/ socsci 8110315

3. Harris J, Mishra P, Koehler M. Teachers' technological pedagogical content knowledge and learning activity types: curriculum-based technology integration refrained. J Res Technol Educ. [Internet]. 2009 [cited Oct 21, 2018];41(4):393-416. Available from: https://files.eric. ed.gov/fulltext/EJ844273.pdf

4. Cheung G, Wan K, Chan K. Efficient Use of Clickers: A Mixed-Method Inquiry with University Teachers. Educ. Sci. 2018;8(31):1-15. doi: https://doi.org/10.3390/ educsci 8010031

5. Schubert V, Medina J, Lenise M. Proceso de construcción del conocimiento pedagógico del docente universitario de enfermería1. Rev. Latino-Am. Enfermagem. [Internet]. 2011 [cited Oct 22, 2018];19(2). Available from: http:// www.scielo.br/pdf/rlae/v19n2/es_26.pdf

6. Cheung G, Wan K, Chan K. Efficient Use of Clickers: A Mixed-Method Inquiry with University Teachers. Educ. Sci. 2018;8(31):1-15. doi: https://doi.org/10.3390/ educsci 8010031

7. Johnson L, Adams S, Estrada V, Freeman A. NMC Horizon Report: 2016 Higher Education Edition. [Internet]. Austin: The New Media Consortium; 2016 [cited Sep 15, 2018]. Available from: http://www.aprendevirtual.org/ centro-documentacion-pdf/2016-nmc-horizon-reportHE-ES.pdf

8. Kapsalis G, Ferrari A, Punie Y, Conrads J, Collado A, Hotulainen $R$, et al. Evidence of Innovative Assessment: Literature Review and Case Studies, EUR 29882. Luxembourg: European Commission; 2019. doi: https://doi.org/10.2760/552774

9. Marcelo C, Yot C, Mayor C. Enseñar con tecnologías digitales en la Universidad. Comunicar. 2015;45:117-24. doi: https://doi.org/10.3916/C45-2015-12

10. Hinojo FJ, Mingorance AC, Trujillo JM, Aznar I, Cáceres MP. Incidence of the Flipped Classroom in the Physical Education Students' Academic Performance in University
Contexts. Sustainability. 2018;10(5):1334-46. doi: https://doi.org/10.3390/su10051334

11. Njie-Carr VP, Ludeman E, Lee MC, Dordunoo D, Trocky NM, Jenkins LS. An Integrative Review of Flipped Classroom Teaching Models in Nursing Education. J Prof Nurs. 2017;33(2):133-44. doi: 10.1016/j. profnurs.2016.07.001

12. Wilson J, Walker S. Turning a crisis into an interactive drama: the introduction of a 'clickers theatre' in nurse education. Nurse Educ Today. 2017;51:109-11. doi: 10.1016 / j.nedt.2016.11.023

13. Carrino SS. Digital connection in a physical classroom: Clickers and the student-teacher relationship [thesis]. Greensboro: University of North Carolina; 2015 [cited Dec 12, 2019]. Available from: https://libres.uncg.edu/ ir/uncg/f/Carrino_uncg_0154D_11791.pdf

14. Zainuddin Z, Halili SH. Flipped classroom research and trends from different fields of study. Int Rev Res Open Distance Learn. [Internet]. 2016 [cited Jul 18, 2018];17(3):313-40. Available from: https://files.eric. ed.gov/fulltext/EJ1102721.pdf

15. Ali RA, Alnatour A, Alnuaimi K, Alzoubi F, Almomani $M$, Othman A. Effects of interactive teaching on university students' knowledge and attitude toward reproductive health: a pilot study in Jordan. J Multidiscip Healthc. 2018;11:211-21. doi: https://doi.org/10.2147/JMDH. S160135

16. Barcelo JM. Medical laboratory science and nursing students' perception of the academic learning environment at a Philippine university using the Dundee Ready Education Environment Measure. J Educ Eval Health Prof. 2016;13(33):1-7. doi: https://doi.org/10.3352/ jeehp.2016.13.33

17. Brady M, Seli H, Rosenthal J. "Clickers" and metacognition: a quasi-experimental comparative study about metacognitive self-regulation and use of electronic feedback devices. Comput Educ. 2013;65:56-63. doi: https://doi.org/10.1016/j.compedu.2013.02.001

18. Castro MJ, López M, Cao MJ, Fernández-Castro M, García S, Frutos $M$, et al. Impact of educational games on academic outcomes of students in the Degree in Nursing. PLoS One. 2019;14(7):e0220388. doi: https:// doi.org/10.1371/journal.pone. 0220388

19. Nishimura A. Effects of different methods of reflection on nurses' gaze and judgement in a task using a touch panel. J Clin Nurs. 2018;27:569-77. doi: https://doi. org/10.1111/jocn. 14096

20. Toothaker R. Millennial's perspective of clicker technology in a nursing classroom: A mixed methods research study. Nurse Educ Today. 2018;62:80-4. doi: https://doi.org/10.1016/j.nedt.2017.12.027

21. Chen TL, Lan YL. Using a personal response system as an in-class assessment tool in the teaching of basic college 
chemistry. Australas J Educ Technol. 2013;29(1):32-40. doi: https://doi.org/10.14742/ajet.95

22. Aktekin NÇ, Çelebi H, Aktekin M. Let's kahoot! Anatomy. Int. J. Morphol. 2018;36(2):716-21. doi: http:// dx.doi.org/10.4067/S0717-95022018000200716

23. Barr ML. Encouraging college student active engagement in learning: The influence of response methods. Innov High Educ. 2013;39(4):307-19. doi: https://doi.org/10.1111/jcal.12205

24. Iskander M. Systematic review of the implementation of audience response systems and their impact on participation and engagement in the education of healthcare professionals. BMJ Simulation \& Technology Enhanced Learning. 2018;4(2):47-50. doi: http://dx.doi. org/10.1136/bmjstel-2017-000245

25. Licorish SA, Owen HE, Daniel, B, George, JL. Students' perception of Kahoot!'s in uence on teaching and learning. RPTEL. 2018;13(9):1-23. doi: https://doi.org/10.1186/ s41039-018-0078-8

26. Oliveira C, Tirapelli C, Rodrigues CT, Domaneschi C, Caldeira SA. Interactive audience response systems in oral and maxillofacial radiology undergraduate lectures. Eur J Dent Educ. [Internet]. 2017;22:63-9. doi: https:// doi.org/10.1111/eje.12258

27. Mohan R. Enhancing student engagement and immediate feedback with clickers and response cards. Int J Innov Learn. 2018;24(1):81-97. doi: https://doi. org/10.1504/IJIL.2018.092924

28. Banks D. Reflections on the use of ARS with small groups. In: Audience Response Systems in Higher

Education: Applications and Cases. Pennsylvania: IGI Global; 2006. p. 373-86.

29. Wood A. Nurse Perceptions of Interactivity during Their Onboarding Orientation: Effect of an Audience Response System [thesis]. Boiling Springs: Hunt School of Nursing; 2017 [cited Dec 12, 2019]. Available from: https:// digitalcommons.gardner-webb.edu/cgi/viewcontent.cgi ?article $=1268 \&$ context $=$ nursing_etd

30. Ismaile S, Alhosban F, Hawamdeh S. Making learning fun to increase nursing students' success: Formative feedback in communication learning. Australas Med $\mathrm{J}$. 2017;10(12):1014-21. doi: https://doi.org/10.21767/ AMJ.2017.3228

31. Castro MJ, López M, Cao MJ, Fernández-Castro M, García S, Frutos M, et al. Impact of educational games on academic outcomes of students in the Degree in Nursing. PLoS One 2019;14(7):e0220388. doi: https:// doi.org/10.1371/journal.pone.0220388

32. Corell A, Regueras LM, Verdú E, Verdú MJ, Castro JP. Effects of competitive learning tools on medi- cal students: A case study. PLoS One. 2018;13(3):e0194096. doi: https://doi.org/10.1371/journal.pone.0194158
33. Oswald KM, Rhoten SE. Improving classroom clicker practices: Effects of incentives and feedback on retention. N Am J Psychol. [Internet]. 2014 [cited Dec 6, 2017];16(1):79-88. Available from: https://www. researchgate.net/publication/285958781_Improving_ classroom_clicker_practices_Effects_of_incentives_and_ feedback_on_retention

34. Marshall LL, Varnon AW. An Empirical Investigation of Clicker Technology in Financial Accounting Principles. J Learn High Educ. [Internet]. 2012 [cited Jun 3, 2018];8(1):7-18. Available from: https://files.eric.ed.gov/ fulltext/EJ1144930.pdf

35. Bojinova ED, Oigara JN. Teaching and learning with Clickers: Are Clickers good for students? Interdiscip J E-Learning Learn Objects. 2011;7:169-83. doi: https:// doi.org/10.28945/1506

36. Benson JD, Szucs KA, DeIuliis E, Leri A. Impact of Student Response Systems on Initial Learning and Retention of Course Content in Health Sciences Students. J Allied Health. [Internet]. 2017 [cited Feb 12, 2018];46(3):15863. Available from: https://www.ingentaconnect.com/ content/asahp/jah/2017/00000046/00000003/art00008 37. Njie-Carr VP, Ludeman E, Lee MC, Dordunoo D, Trocky NM, Jenkins LS. An Integrative Review of Flipped Classroom Teaching Models in Nursing Education. J Prof Nurs. 2017;33(2):133-44. doi: 10.1016/j. profnurs.2016.07.001

38. Rana NP, Dwivedi YK. Can clicking promote learning? measuring student learning performance using clickers in the undergraduate information systems class. J Int Educ Bus. 2017;10(2):201-15. doi: http://doi.org/10.1108/ JIEB-06-2016-0010

39. Iwamoto D, Hargis J, Taitano E, Vuong K. Analyzing the efficacy of the testing effect using kahoottm on student performance. Turkish Online J Distance Educ. [Internet]. 2017;18(2):93-80. doi: https://doi.org/10.17718/ tojde. 306561

40. George C, Gallegos C, Tesar AJ, Connor K, Martz K. The use of a game-based learning platform to engage nursing students: A descriptive, qualitative study. Nurse Educ Pract. 2017;27:101-6. doi: https://doi.org/10.1016/j. nepr.2017.08.019.

41. Kalaian SA, Kasim RM. Effectiveness of various innovative learning methods in health science classrooms: a meta-analysis. Adv Health Sci Educ Theory Pract. [Internet]. 2017;22(5):1151-67. doi: https://doi. org/10.1007/s10459-017-9753-6

42. Maloney LM, Dilger JP, Werfel PA, Cimino LM. Are Audience Response Systems Worth the Cost ? Comparing Question-Driven Teaching Strategies for Emergency Medical Technician Education. Internet J Allied Health Sci Pract. [Internet]. 2017 [cited May 7, 2018];16(1):1- 
8. Available from: https://nsuworks.nova.edu/cgi/ viewcontent.cgi?article $=1704 \&$ context $=$ ijahsp

43. Ismail MA, Mohammad JA. Kahoot: A promising tool for formative assessment in medical education. Educ Med J. 2017;9(2):19-26 doi: https://doi.org/10.21315/ eimj2017.9.2.2

44. Nikou SA, Economides AA. Mobile-based assessment: A literature review of publications in major referred journals from 2009 to 2018. Comput Educ. 2018;125:10119. doi: https://doi.org/10.1016/j.compedu.2018.06.006 45. Montejano-Lozoya R, Gea-Caballero V, Miguel-Montoya I, Juárez-Vela R, Sanjuán-Quiles A, Ferrer-Ferrandiz E. Validation of a questionnaire designed to measure nursing student satisfaction with practical training. Rev. LatinoAm. Enfermagem. 2019;27:e3206. doi: https://doi. org/10.1590/1518-8345.3102.3206

46. Miles NG, Soares TP. Acceptance of clickers in a large multimodal biochemistry class as determined by student evaluations of teaching: Are they just an annoying distraction for distance students? Biochem Mol Biol Educ. 2016; Oct;44(1):99-108. doi: https://doi.org/10.1002/ bmb. 20917

47. Yeh CR, Tao YH. How benefits and challenges of personal response system impact students' continuance intention? A Taiwanese context. Educ Technol Soc. [Internet]. 2013 [cited Jan 10, 2018];16(2):257-70. Available from: https://pdfs.semanticscholar.org/283d/ f5d6cddabfc9abb8d2806efbf809975818cb.pdf

48. Lin YC, Liu TC, Chu CC. Implementing clickers to assist learning in science lectures: The clicker-assisted conceptual change model. Australas J Educ Technol. 2011;27(6):979-96. doi: https://doi.org/10.14742/ ajet. 924

49. Kline R. Principles and Practice of Structural Equation Modeling. New York: The Guilford Press; 2011.

\section{Authors' Contribution:}

Study concept and design: Ángel Custodio MingoranceEstrada. Obtaining data: Ángel Custodio MingoranceEstrada, Gloria Rojas-Ruiz. Data analysis and interpretation: Ángel Custodio Mingorance-Estrada, Juan Granda-Vera, Inmaculada Alemany-Arrebola. Statistical analysis: Juan Granda-Vera, Inmaculada AlemanyArrebola. Drafting the manuscript: Ángel Custodio Mingorance-Estrada, Gloria Rojas-Ruiz. Critical review of the manuscript as to its relevant intellectual content: Ángel Custodio Mingorance-Estrada.

All authors approved the final version of the text.

Conflict of interest: the authors have declared that there is no conflict of interest.
Received: Dec $12^{\text {th }} 2019$ Accepted: Aug $13^{\text {th }} 2020$

Associate Editor: Regina Aparecida Garcia de Lima

Copyright () 2021 Revista Latino-Americana de Enfermagem This is an Open Access article distributed under the terms of the Creative Commons (CC BY).

This license lets others distribute, remix, tweak, and build upon your work, even commercially, as long as they credit you for the original creation. This is the most accommodating of licenses offered. Recommended for maximum dissemination and use of licensed materials. 